\title{
Keikutsertaan Care Giver Dalam Menerapkan Terapi ABA (Applied Behaviour Analysis) Pada Anak Autis
}

\author{
Fitri Kurniati Agustina ${ }^{1}$, Feri Kameliawati ${ }^{2 *)}$, Rika Damayanti $^{3}$ \\ Fakultas Kesehatan Program Studi Ilmu Keperawatan Universitas Aisyah Pringsewu \\ e-mail: kameliawatiferi@gmail.com
}

\begin{abstract}
Abstrak. Masih rendahnya peran serta orang tua yang memiliki anak dengan autis dapat disebabkan motivasi orang tua untuk mencapai kesembuhan anak dan tingkat kesadaran akan peran aktif orang tua. Untuk mencapai kesembuhan yang diiringi dengan kesadaran akan pentingnya peran aktif akan mendorong orang tua meningkatkatkan pengetahuan. Tujuan penelitian ini adalah untuk mengetahui keikutsertaan care giver dalam menerapkan terapi ABA (Applied Behaviour Analysis) pada anak autis di Pusat Terapi LPSDM Graha Jiwa Indonesia Kabupaten Pringsewu tahun 2014. Metode kualitatif dengan pendekatan fenomenologi digunakan untuk menggali partisipasi orang tua terhadap terapi perubahan perilaku anak autis dengan menerapkan terapi ABA. Pengambilan sampel berdasarkan pada tingkat pemenuhan terhadap informasi yang ingin dicapai dalam penelitian yaitu berjumlah 4 responden. Data dikumpulkan melalui wawancara mendalam dilengkapi dengan catatan lapangan kemudian dibuat transkip wawancara dan dilakukan analisis data yang dimulai dari mendengarkan rekaman hasil wawancara sampai membuat kesimpulan atas data kualitatif yang diperoleh. Hasil penelitian mengungkapkan bahwa sebagian responden tidak begitu tahu tentang metode ABA yang diberikan terapis dan sebagaian responden sangat memperhatikan kebutuhan anaknya melebihi anak yang lainnya karena baginya anak autis memang menuntut pemenuhan kebutuhan yang ekstra atau spesial dibanding anak normal. Oleh karena itu keluarga dengan anak autis harus tetap memberikan proses terapi yang memadai seperti pemilihan tempat terapi yang baik dengan terapis yang berkompeten di bidangnya seperti memberikan terapi-terapi ringan di rumah.
\end{abstract}

Kata kunci: Care giver, terapi ABA, Autis.

\section{Pendahuluan}

Anak autis merupakan anak dengan "special needs" atau anak dengan kebutuhan khusus. Anak autis merupakan anak yang mengalami hambatan dalam perkembangan perilakunya. Gejala yang tampak pada anak autis yaitu tidak mampu bersosialisasi, mengalami kesulitan menggunakan bahasa, berperilaku berulang-ulang, serta bereaksi tidak bisa terhadap rangsangan sekitarnya, sehingga apabila hambatan ini tidak diatasi sedini mungkin maka proses belajar anak-anak tersebut juga terhambat, seperti intelegensi, emosi, dan perilaku sosialnya tidak dapat berkembang dengan baik. Oleh karena itu sangat penting untuk melakukan deteksi sedini mungkin bagi anak-anak ini. (Handoyo, 2003).

Berdasarkan data dari UNESCO pada tahun 2011 tercatat 35 juta orang penyandang autisme di seluruh dunia, dan ini berarti rata-rata 6 dari 1000 orang di dunia mengidap autisme. Sedangkan penelitian Center for Disease Control (CDC) di Amerika (2008), menyatakan bahwa perbandingan autisme pada anak umur 8 tahun yang terdiagnosa dengan autisme adalah 1 : 80. Berdasarkan data dari Departemen Pendidikan Amerika bahwa angka peningkatan penyandang autisme di Amerika cukup mengerikan, yaitu sebesar 10\% sampai 17\% pertahun. Jumlah penyandang autime di Amerika Serikat saat ini sebanyak 1,5 juta orang 
anak. Pada dekade berikut diperkirakan terdapat sekitar empat juta penyandang autisme di Amerika (Nakita, 2002).

Metode ABA, khususnya untuk kemampuan bersosialisasi dapat membantu anak autis mempelajari keterampilan sosial dasar seperti memperhatikan, mempertahankan kontak mata, dan dapat membantu mengontrol masalah perilaku. Peran aktif orang tua dalam usaha membantu anak menjalankan terapi merupakan salah satu faktor penting karena tanpa dukungan orang tua proses untuk memcapaia kesembuhan akan berjalan lebih lama. Hasil wawancara dengan salah satu anggota terapis telah melaksanakan suatu kegiatan yang diharapkan menambah pengetahuan orang tua dalam keikutsertaannya, tetapi pada kenyataannya masih ada beberapa orang tua masih belum memahami peran sertanya dalam merawat anak dengan autisme.

Tujuan dari penelitian ini adalah mengetahui keikutsertaan care giver dalam menerapkan terapi ABA (Applied Behaviour Analysis) pada anak autis

\section{Metode}

Rancangan penelitian ini adalah eksploratif dengan tujuan menggambarkan partisipasi orang tua terhadap terapi perubahan perilaku anak autis dengan menerapkan terapi ABA di Pusat Terapi LPSDM Graha Jiwa Indonesia Kabupaten Pringsewu, melalui pendekatan fenomenologi yaitu berfokus pada penemuan fakta mengenai tingkah laku manusia berdasarkan perseptif responden. Metode ini memahami manusia dengan segala kompleksitas sebagai makhluk subyektif, melihat manusia sebagai sistem yang berpola dan berkembangan (Poerwandari, 2005).

Variabel dalam penelitian ini adalah variabel tunggal yaitu keikutsertaan orang tua dalam penerapan terapi ABA pada anak autis di Pusat Terapi LPSDM Graha Jiwa Indonesia Kabupaten Pringsewu.

Populasi dalam penelitian ini adalah semua orang tua yang mempunyai anak dengan autis di Pusat Terapi LPSDM Graha Jiwa Indonesia Kabupaten Pringsewu yang berjumlah 14 orang. Jumlah sampel dalam penelitian ini adalah 4 responden, pada penelitian kualitatif tidak mempersoalkan sampel penelitian, besar sampel lebih didasarkan pada tingkat pemenuhan terhadap informasi yang ingin dicapai dalam penelitian.

Instrumen yang digunakan dalam pengumpulan data pada penelitian ini adalah peneliti sendiri, pedoman wawancara yang disusun oleh peneliti meliputi pertanyaan mengenai hal-hal yang diketahui orang tua terhadap terapi ABA. Metode yang digunakan dalam penelitian ini adalah wawancara mendalam sehingga data yang didapatkan merupakan data primer. Alat bantu yang dipergunakan adalah audio visual berupa handphone yang digunakan untuk merekam hasil wawancara, lembar pertanyaan dan buku catatan lapangan seperti buku tulis dan pena.

Untuk meningkatkan validitas muka (face validity) dan konstruk dari variabel yang akan diteliti dilakukan uji coba (uji pemahaman). Untuk mengetahui keabsahan data, dilakukan triangulasi sumber dengan melakukan cek ulang dan cek silang. Cek ulang dilakukan dengan mencocokkan kembali ringkaan wawancara kepada responden untuk mendapatkan reaksi atau menguji kembali pada data rekaman. Cek silang dilakukan dengan membandingkan hasil wawancara responden dengan komentar anak autis untuk mendapatkan kebenaran, sehingga pencocokan ini berpeluang untuk menangkap maksud, mengklarifikasi dengan anak atau mendapatkan informasi tambahan. 
Analisa data kualitatif dalam penelitian ini dilakukan segera setelah data diperoleh, berlangsung sejak pengambilan data dimulai.

1. Mendengarkan rekaman dan membaca catatan-catatan penting atau kata kuncia saat wawancara kemudian membuat salinan data keseluruhan atau transkip, sesuai apa adanya untuk mengetahui kelengkapan dan kesinambungan data segera setelah data diperoleh.

2. Melakukan klarifikasi data hasil wawancara berupa transkip yang telah dibuat kepada responden, untuk memastikan apakah sudah sesuai dengan apa yang disampaikan oleh responden atau belum.

3. Melakukan proses identifikasi, koding dan mengkategorikan pola-pola utama yang ditemukan dalam data setiap responden. Peneliti melakukan seleksi terhadap data yang diperoleh dengan melihat data yang dianggap sesuai dengan pokok permasalahan.

4. Membuat kesimpulan atas data kualitatif yang diperoleh.

Penyajian dari data yang diperoleh dituangkan dalam bentuk "kutipan responden dalam bentuk aslinya", penjelasan asli dari responden disajikan sebagai bagian dari kalimat apabila tidak cukup panjang atau terpisah dalam paragraf sendiri jika cukup panjang.

\section{Hasil dan Pembahasan}

Setelah membaca berulang-ulang hasil transkip wawancara dan catatan lapangan dari masingmasing responden, peneliti mengidentifikasi kutipan kata dan pernyataan bermakna yang berhubungan dengan fenomena penelitian, kemudian membuat kategori-kategori, menentukan tema. Berikut hasil wawancara yang peneliti dapatkan:

a. Kemampuan keluarga/care giver dalam mengenal masalah kesehatan keluarga dan memutuskan tindakan yang tepat bagi keluarga

Berdasarkan hasil wawancara bahwa sebagian besar orang tua sudah mengetahui anaknya menderita autis tetapi belum mengetahui tentang penyebab dan faktor terjadinya anak autis. Sebagian besar responden mengatasi masalah yang dialami oleh anaknya dengan bertanya pada orang yang dikenal dan mencari tahu melalui internet untuk melakukan tindakan yang tepat bagi anaknya yang mengalami gangguan.

b. Kemampuan keluarga/care giver dalam memutuskan tindakan kesehatan yang tepat

c. Sebagaian responden sangat memperhatikan kebutuhan anaknya melebihi anak yang lainnya karena baginya anak autis memang menuntut pemenuhan kebutuhan yang ekstra atau spesial dibanding anak normal meskipun kebutuhan atau fasilitas yang diberikan tidak begitu dimengerti oleh anaknya dan orang tua juga tidak tahu tentang metode ABA yang diberikan terapis,

d. Kemampuan keluarga/care giver dalam merawat anggota keluarga yang mengalami gangguan kesehatan

Keluarga sangat toleran dalam mengasuh anaknya yang autis, tidak menerapkan suatu pola pengasuhan khusus, namun keluarga sangat memperhatikan aktivitas anaknya dan berusaha untuk selalu mengikuti aktivitasnya. Sebagian keluarga ada yang mengasuh sebatas yang diketahuinya saja.

e. Kemampuan keluarga/care giver dalam memodifikasi lingkungan keluarga untuk menjamin kesehatan keluarga

Sebagian kecil responden saat di rumah melakukan terapi mengontrol emosi anaknya dengan cara memberikan perhatian lebih kepada anaknya seperti memberikan aturan- aturan sederhana dalam menata perilaku anaknya, seperti waktu makan dan tidur, lalu bagaimana buang air besar dan buang air kecil, 
Sebagian responden sangat memperhatikan kebutuhan anaknya melebihi anak pertamanya karena baginya anak autis memang menuntut pemenuhan kebutuhan yang ekstra atau spesial dibanding anak normal meskipun kebutuhan atau fasilitas yang diberikan tidak begitu dimengerti oleh anaknya.

f. Kemampuan keluarga/care giver dalam memanfaatkan fasilitas kesehatan

Ada responden yang lebih suka membawa anaknya ke fasilitas terapi terdekat dari rumahnya daripada harus jauh-jauh berkonsultasi dengan dokter atau mencari fasilitas lain. Sebagian anak responden memiliki masalah khusus seperti saat di terapi di rumah anak kadang-kadang memberontak.

\section{Kesimpulan dan Saran}

Penelitian ini menjelaskan keikutsertaan keluarga/care giver dalam menerapkan terapi metode ABA pada anak autis yang terasa manfaatnya secara langsung dengan melaksanakan tugas keluarga dalam bidang kesehatan yaitu dalam mengenal masalah kesehatan keluarga, memutuskan tindakan yang tepat bagi keluarga, merawat keluarga yang mengalami gangguan kesehatan, memodifikasi lingkungan untuk menjamin kesehatan keluarga, dan memanfaatkan fasilitas kesehatan yang ada di sekitarnya.

Bagi keluarga dengan anak autis harus tetap memberikan proses terapi yang memadai seperti pemilihan tempat terapi yang baik dengan terapis yang berkompeten di bidangnya, memberikan terapiterapi ringan di rumah yang bisa dilakukan oleh anggota keluarga bagi anak autis agar perkembangan sosio-emosionalnya semakin terlihat.

Bagi peneliti lain disarankan untuk dapat melakukan penelitian lanjutan tentang pentingnya peran keluarga dalam perkembangan kontak mata anak autis sebagai berikut :

a. Melibatkan karakteristik subyek yang lebih bervariasi dalam hal latar belakang sosial budaya dan status ekonomi agar dapat menggali keragaman aspek peran keluarga dalam perkembangan anak autis.

b. Perlu mengeksplorasi lebih mendalam mengenai beberapa aspek peran keluarga dalam perkembangan anak autis.

\section{Daftar Pustaka}

Amelia, E. 2004. Pola Komunikasi Keluarga Anak Autisme Dalam Masa Terapi. Tugas Akhir. Universitas Indonesia.

Arifin, Z. 2010. Penelitian Pendidikan Metode dan Paradigma Baru. Bandung : RemajaRosdakarya

Arni, S. 2002. Tingkat Penerimaan Orang Tua Dikaitkan Dengan Usia Anak yang Menderita Autisme di RSU Cipto Mangunkusumo Jakarta. Jurnal.

Badan Pusat Statistik, 2010, Informasi Mengenai Autisme dan Pendidikannya. Tersedia http: // www.ditbb.or.id//new [28 April 2014]

Chandra, D. 2002. Studi Komparasi Antara PTD dengan Pendekatan CTL dam mapel yang diajarkan dengan CTL. Makalah.

Danuatmaja, B. 2003. Terapi anak Autis di Rumah. Cetakan I. Jakarta : Puspa Swara. 
Ebin, S. 2005. Pengaruh Pola Asuh Orang Tua Dengan Kedisiplinan Siswa Kelas I dan II di SMU Negeri 8 Medan Tahun Ajaran 2004/2005, Medan: Skripsi Unimed.

Edward, D. 2006. Ketika Anak Sulit Diatur : Panduan Orang Tua Untuk Mengubah Masalah Perilaku Anak. Bandung : PT. Mizan Utama.

Fitriyani. 2007. Efektivitas Terapi Wicara Pada Anak Autis Dengan Gangguan Perkembangan Bahasa. Malang: Fakultas Psikologi Universitas Islam Negeri Malang.

Friedman, 2013. Buku Ajar Keperawatan Keluarga Riset, Teori dan Praktik. Edisi 5. Jakarta : EGC.

Ginanjar, AS. 2007. Memahami Spektrum Autis Secara Holistik. Jakarta: Fakultas Psikologi Universitas Indonesia.

Green, G. 2008. Autism and ABA. Jakarta: Gramedia. 